\title{
Effects of urea supplementation on ruminal fermentation characteristics, nutrient intake, digestibility, and performance in sheep: A meta-analysis
}

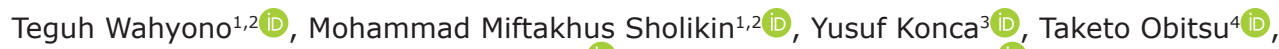 \\ Sadarman Sadarman 2,5 and Anuraga Jayanegara 2,6 (D)
}

1. National Research and Innovation Agency of Indonesia, Jakarta 10340, Indonesia; 2. Animal Feed and Nutrition Modelling Research Group, Faculty of Animal Science, IPB University, Bogor 16680, Indonesia; 3. Department of Animal Science, Faculty of Agriculture, Erciyes University, Kayseri 38039, Turkey; 4. Department of Animal Science, Graduate School of Biosphere Science, Hiroshima University, 1-4-4 Kagamiyama, Higashi-Hiroshima, Hiroshima 739-8528, Japan;

5. Department of Animal Science, UIN Sultan Syarif Kasim, Pekanbaru 28293, Indonesia; 6. Department of Animal Nutrition and Feed Technology, Faculty of Animal Science, IPB University, Bogor 16680, Indonesia.

Corresponding author: Teguh Wahyono, e-mail: teguhwahyono@batan.go.id

Co-authors: MMS: mohammadmiftakhussholikin@gmail.com, YK: yusufkonca@erciyes.edu.tr,

TO: tobitsu@hiroshima-u.ac.jp, SS: sadarman@uin-suska.ac.id, AJ: anuragaja@apps.ipb.ac.id Received: 19-07-2021, Accepted: 12-01-2022, Published online: 15-02-2022

doi: www.doi.org/10.14202/vetworld.2022.331-340 How to cite this article: Wahyono T, Sholikin MM, Konca Y, Obitsu T, Sadarman S, Jayanegara A (2022) Effects of urea supplementation on ruminal fermentation characteristics, nutrient intake, digestibility, and performance in sheep: A meta-analysis, Veterinary World, 15(2): 331-340.

\begin{abstract}
Background and Aim: As a non-protein nitrogen source, urea is a popular, low cost, and easily obtained protein supplement. The objective of the present study was to perform a meta-analysis of the effects of urea supplementation on rumen fermentation and sheep performance.

Materials and Methods: A total of 32 experiments from 21 articles were compiled into a dataset. The levels of dietary urea varied from 0 to $31 \mathrm{~g} / \mathrm{kg}$ of dry matter (DM). Parameters observed were rumen fermentation product, nutrient intake, nutrient digestibility, and sheep performance. This dataset was analyzed using a mixed model methodology, with urea supplementation levels as fixed effects and the different experiments as random effects.

Results: Increasing levels of urea were associated with increases $(\mathrm{p}=0.008)$ in rumen $\mathrm{pH}$, butyrate $\left(\mathrm{C}_{4}\right)$ production, and ammonia $\left(\mathrm{NH}_{3}-\mathrm{N}\right)$ concentration. Urea supplementation had minor effects on total volatile fatty acids $(\mathrm{p}=0.242)$, total protozoa $(\mathrm{p}=0.429)$, and the microbial $\mathrm{N}$ supply $(\mathrm{p}=0.619)$, but tended to increase methane production $\left(\mathrm{CH}_{4} ; \mathrm{p}<0.001\right)$. Supplementation of urea increased the intake of dry matter $(\mathrm{DM} ; \mathrm{p}=0.004)$ and crude protein $(\mathrm{CP} ; \mathrm{p}=0.001)$. Digestibility parameters, such as DM digestibility (DMD) and CP digestibility $(\mathrm{CPD})$, also increased $(\mathrm{p}<0.01)$ as a result of urea supplementation. Retained $\mathrm{N}(\mathrm{p}=0.042)$ and $\mathrm{N}$ intake $(\mathrm{p}<0.001)$ were higher with increasing levels of urea supplementation. In terms of animal performance, supplementation of urea increased average daily gain ( $\mathrm{ADG} ; \mathrm{p}=0.024$ ), but decreased the hot carcass weight percentage $(\mathrm{p}=0.017)$.
\end{abstract}

Conclusion: This meta-analysis reports the positive effects of urea supplementation on rumen fermentation products (i.e., $\mathrm{pH}, \mathrm{C}_{4}$, and $\mathrm{NH}_{3}-\mathrm{N}$ ), intake (DM, CP, and $\mathrm{N}$ ), digestibility (DMD and $\mathrm{CPD}$ ), and $\mathrm{ADG}$ in sheep.

Keywords: meta-analysis, sheep, supplementation, urea.

\section{Introduction}

In rural development, sheep are one of the most important livestock animals supporting economic activities; therefore, strategies to increase sheep production through feed supplementation must be carefully considered. As a non-protein nitrogen (NPN) source, urea is a reasonable protein replacement due to its low cost, ease of obtainability, and high $\mathrm{N}$ density [1]. Furthermore, urea is a popular N source for small and industrial farming because of its lower cost per unit of $\mathrm{N}$ compared with other protein sources [2].

Copyright: Wahyono, et al. Open Access. This article is distributed under the terms of the Creative Commons Attribution 4.0 International License (http://creativecommons.org/licenses/ by/4.0/), which permits unrestricted use, distribution, and reproduction in any medium, provided you give appropriate credit to the original author(s) and the source, provide a link to the Creative Commons license, and indicate if changes were made. The Creative Commons Public Domain Dedication waiver (http:// creativecommons.org/publicdomain/zero/1.0/) applies to the data made available in this article, unless otherwise stated.
Urea is utilized by rumen microbes, which convert it to ammonia and subsequently to microbial protein, thus increasing the supply of protein available to the host [3].

Various studies have generally reported positive effects of urea application as a feed supplement for ruminants [3-6]. Urea supplementation to animals may stimulate nutrient digestibility and improve performance and carcass yield [4]. Urea at $10 \mathrm{~g} / \mathrm{kg}$ of dry matter (DM) can be used as a substitute for $75 \%$ of soybean meal in fattening lambs without decreasing nutrient utilization, rumen fermentation, or animal performance [5]. In addition, the supplementation of urea $(10-15 \mathrm{~g} / \mathrm{kg} \mathrm{DM})$ improves the digestibility of $\mathrm{DM}$, organic matter $(\mathrm{OM})$, and crude protein $(\mathrm{CP})$. In sheep, it increases rumen microbial $\mathrm{N}$, ammonia, and volatile fatty acid (VFA) concentration [6]. Conversely, some studies have reported that urea has no positive effects on sheep $[1,2]$. For instance, in 
one study, urea supplementation $(3.5 \mathrm{~g} / \mathrm{kg} \mathrm{DM})$ was shown to have no effect on DM intake (DMI) or ruminal available $\mathrm{N}$ [2]. In another study, supplementation of $25 \mathrm{~g} / \mathrm{kg}$ DM urea in a 50:50 concentrate-to-roughage ratio decreased the DMI and average daily gain (ADG) of sheep [1].

The utilization efficiency of $\mathrm{N}$ supplementation may vary according to the different methods and levels of supply [3]. In addition, differences in research design, statistics, animal breed, and other technical conditions can produce variation in experimental results. These challenges can be overcome with the use of meta-analysis, a thorough statistical procedure for analyzing a combined dataset obtained from multiple research experiments [7,8]. Sauvant et al. [7] reported that many publications conducted meta-analysis of $\mathrm{N}$ supplementation and proved it widely accepted, especially in ruminant nutrition. A recent meta-analysis study conducted by Salami et al. [8], who reported that the effects of slow-release urea (SRU) supplementation supported improvements in the live weight gain (LWG) and feed efficiency (FE) in beef cattle.

To the best of our knowledge, there is no published meta-analysis of the effect of urea supplementation in sheep. Although both cattle and sheep are ruminants, sheep can change digestible $\mathrm{N}$ into absorbed amino acid-N at a much greater rate than cattle [9]. Furthermore, although $\mathrm{N}$ intake is positively correlated with fecal $\mathrm{N}$ excretion in all types of ruminants, in sheep, this effect is not statistically significant [10].

Therefore, the present meta-analysis aimed to investigate the influence of urea supplementation on rumen fermentation, nutrient utilization, and production performance in sheep.

\section{Materials and Methods}

\section{Ethical approval}

This is a meta-analysis of the published studies and ethical approval is not required for this study.

\section{Metadata development}

A dataset was compiled from published experiments that reported the influence of urea supplementation on rumen fermentation, nutrient intake, digestibility, and performance in sheep. Literatures were collected from the period 1996 to 2019. The included studies were obtained from the Scopus because it is considered as one of the most comprehensive electronic databases of scientific articles. The articles were identified through searches using "urea," "supplementation," and "sheep" as keywords. Inclusion criteria for an article were as follows: (1) The article was published in English; (2) experiments were performed based on conventional urea, not SRU, as described by Sevim and Önol [11]; (3) dietary urea supplementation level was reported; and (4) all parameters were directly measured rather than estimated using predictive equations. After abstract and full-text evaluations, a total of 21 articles (describing a total of 32 experiments) met the inclusion criteria (Table-1) [1-6,12-26]
When a published study reported more than 1 experiment, each individual entity was encoded separately. All experiments were performed directly (in vivo) and any in vitro experiments using rumen fluid taken from sheep were excluded from the study. The concentration of urea in the present meta-analysis ranged from 0 to $31 \mathrm{~g} / \mathrm{kg} \mathrm{DM}$, and the experimental periods varied from 15 to 85 days.

The rumen fermentation parameters included in the dataset were $\mathrm{pH}$, total VFA, acetate $\left(\mathrm{C}_{2}\right)$, propionate $\left(\mathrm{C}_{3}\right)$, butyrate $\left(\mathrm{C}_{4}\right)$, isobutyrate $\left(\right.$ iso $\left._{4}\right)$, valerate $\left(\mathrm{C}_{5}\right)$, isovalerate $\left(\right.$ iso $\left._{5}\right)$, ammonia $\mathrm{N}\left(\mathrm{NH}_{3}-\mathrm{N}\right)$, methane emissions $\left(\mathrm{CH}_{4}\right)$, total protozoa, and microbial $\mathrm{N}$ supply. The included nutrient intake and digestibility parameters were DMI, OM intake (OMI), CP intake (CPI), metabolizable energy intake (MEI), non-fiber carbohydrate intake (NFCI), neutral detergent fiber intake (NDFI), acid detergent fiber intake (ADFI), DM digestibility (DMD), OM digestibility (OMD), CP digestibility (CPD), non-fiber carbohydrate digestibility (NFCD), neutral detergent fiber digestibility (NDFD), acid detergent fiber digestibility (ADFD), $\mathrm{N}$ intake, and retained $\mathrm{N}$. The assessed sheep performance parameters were ADG, FE, hot carcass weight $(\mathrm{HCW})$, and cold carcass weight (CCW).

\section{Preferred reporting items for systematic reviews and meta-analyses (PRISMA) guideline}

This study used the protocol described by PRISMA guidelines [27]. We selected and extracted the data according to the PRISMA protocols (Figure-1).

\section{Statistical analysis}

A meta-analysis was performed using a statistical analysis based on a mixed model methodology [28,29]. Accordingly, different studies were treated as random effects, whereas the levels of urea supplementation in sheep diets were treated as fixed effects. The mathematical models used were as follows:

$$
\begin{aligned}
Y_{i j}= & \beta_{0}+\beta_{1} \text { Level }_{i j}+\text { Experiment }_{i}+ \\
& \text { Experiment }_{i} \text { Level }_{i j}+e_{i j} \\
Y_{i j}= & \beta_{0}+\beta_{1} \text { Level }_{i j}+\beta_{2} \text { Level }_{i j}{ }^{2}+\text { Experiment }_{i}+ \\
& \text { Experiment }_{i} \text { Level }_{i j}+e_{i j}
\end{aligned}
$$

Where, Equation 1 is the linear mixed model of the $1^{\text {st }}$ order (linear model), and Equation 2 is the linear mixed model of the $2^{\text {nd }}$ order (quadratic model). Model statistics used were $p$-value and root mean square error (RMSE). The result was significant if the p-value was less than or equal to 0.05 , and if the p-value ranged from 0.05 to 0.1 , there was a tendency to be significant. The model implemented was the quadratic ( $2^{\text {nd }}$ order) version, and this was then assessed to its linear model ( $1^{\text {st }}$ order) when the quadratic term was non-significant. All statistical analyses were performed in R software version 3.6.3 equipped with an "nlme" library [30].

\section{Results}

Effect of urea supplementation on rumen fermentation in sheep

The effect of urea supplementation on the rumen fermentation parameters is outlined in Table-2. 
Table-1: Experiments included in the meta-analysis of the effect of urea supplementation on rumen fermentation and sheep performance.

\begin{tabular}{|c|c|c|c|c|c|}
\hline $\begin{array}{l}\text { Study } \\
\text { no. }\end{array}$ & Reference & Method & Basal feed & Breed of sheep & $\begin{array}{c}\text { Addition level } \\
\text { (g/kg dry matter) }\end{array}$ \\
\hline 1 & {$[18]$} & In vivo & $\begin{array}{l}\text { Eragrostis and lucerne hay-sunflower } \\
\text { meal and ground maize }(43: 57 \mathrm{w} / \mathrm{w})\end{array}$ & Merino & 0 and 10 \\
\hline 2 & [3] & In vivo & $\begin{array}{l}\text { Maize stover, ground corn, and } \\
\text { cottonseed meal }\end{array}$ & Merino & $0 ; 7 ;$ and 15 \\
\hline 3 & [1] & In vivo & $\begin{array}{l}\text { Soybean hull, corn, soybean meal, and } \\
\text { wheat bran }\end{array}$ & Dorper $\times$ Thin tailed & $0 ; 5 ; 15 ;$ and 25 \\
\hline 4 & [20] & In vivo & TMR pellet & Poll Dorset Sire×Dohne & 0 and 15 \\
\hline 5 & {$[2]$} & In vivo & $\begin{array}{l}\text { Hard fescue (Festuca trachyphylla) } \\
\text { straw }\end{array}$ & Rambouillet×Polypay & 0 and 3.5 \\
\hline 6 & {$[6]$} & In vivo & $\begin{array}{l}\text { Berseem (Trifolium alexandrinum) } \\
\text { hay-concentrate }(60: 40 \mathrm{w} / \mathrm{w})\end{array}$ & Barki & $0 ; 10 ;$ and 15 \\
\hline 7 & [14] & In vivo & $\begin{array}{l}\text { Barley, corn, soybean meal, and barley } \\
\text { straw }\end{array}$ & Assaf & $0 ; 6$; and 9.5 \\
\hline 8 & {$[5]$} & In vivo & Corn silage, peanut vine, and corn grain & $\mathrm{Hu}$ & $0 ; 10 ; 20 ;$ and 30 \\
\hline 9 & [22] & In vivo & Oat hay & Rambouillet $\times$ Kaghani & $0 ; 5 ;$ and 10 \\
\hline 10 & [12] & In vivo & $\begin{array}{l}\text { Dwarf elephant grass (Pennisetum } \\
\text { purpureum Schum. Cv. Mott) hay }\end{array}$ & Polwarth $\times$ Texel & 0 and 10 \\
\hline 11 & [23] & In vivo & Grass hay (Cynodon sp.) & Polwarth $\times$ Texel & 0 and 10 \\
\hline 12 & [24] & In vivo & $\begin{array}{l}\text { Wheat straw, barley grain, wheat grain, } \\
\text { wheat bran, and sunflower meal }\end{array}$ & Merino & $0 ; 6 ; 12 ;$ and 18 \\
\hline 13 & [16] & In vivo & Acacia saligna and wheat straw & Merino & 0 and 10 \\
\hline 14 & [15] & In vivo & Timothy hay and ground corn & Corriedale $\times$ Suffolk & 0 and 31 \\
\hline 15 & [26] & In vivo & Para grass and soybean meal & Phan Rang & 0 and 18 \\
\hline 16 & [19] & In vivo & Timothy hay and soybean meal & Corriedale $\times$ Suffolk & 0 and 9 \\
\hline 17 & [4] & In vivo & Buffelgrass & 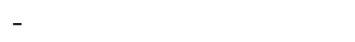 & $5 ; 8 ; 11 ;$ and 14 \\
\hline 18 & [13] & In vitro & Cotton straw and maize meal & Karakul & $0 ; 10 ; 20 ;$ and 30 \\
\hline 19 & [17] & In vivo & Oat or barley straw & Merino×Romney & 0 and 10 \\
\hline 20 & [25] & In vivo & Oaten chaff hay, oats, and lupins & Merino & 0 and 20 \\
\hline 21 & [21] & In vivo & Veld hay or Napier hay & Dorper $\times$ Merino & $0 ; 10 ;$ and 20 \\
\hline
\end{tabular}

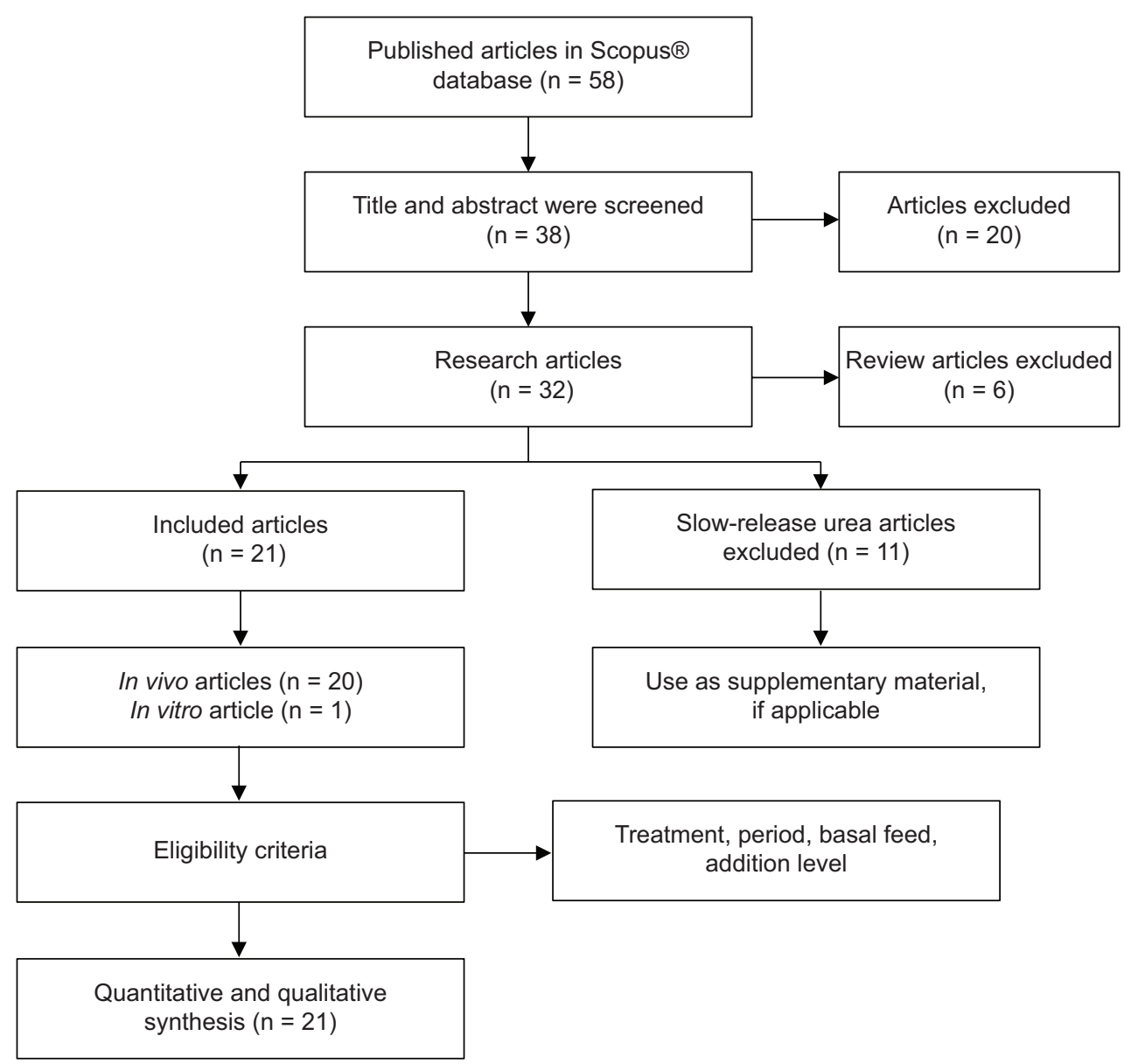

Figure-1: Diagram of literature search. 
Increasing urea levels were associated with an increase in rumen $\mathrm{pH}(\mathrm{p}=0.008)$. The addition of urea did not change the total VFA production. With regard to VFA composition, the proportions of $\mathrm{C}_{4}$ and iso $\mathrm{C}_{4}$ increased $(\mathrm{p}=0.033)$ and decreased $(\mathrm{p}=0.006)$, respectively, as a result of urea supplementation. Urea supplementation did not change the proportions of $\mathrm{C}_{2}, \mathrm{C}_{3}, \mathrm{C}_{5}$, iso $\mathrm{C}_{5}$, or $\mathrm{C}_{2}: \mathrm{C}_{3}$. An increase in rumen $\mathrm{NH}_{3}-\mathrm{N}(\mathrm{p}=0.012)$ and enteric $\mathrm{CH}_{4}(\mathrm{p}=0.0006)$ was associated with increasing levels of urea supplementation. Urea supplementation had a minor effect on the total protozoa population $(\mathrm{p}=0.429)$ and microbial $\mathrm{N}$ supply $(\mathrm{p}=0.619)$.

\section{Effect of urea supplementation on nutrient intake and digestibility in sheep}

Urea supplementation increased the intake of DM $(\mathrm{p}=0.004), \mathrm{ME}(\mathrm{p}=0.013)$, and $\mathrm{CP}(\mathrm{p}=0.001)$, but did not influence OMI, NFCI, NDFI, or ADFI (Table-3). Digestibility parameters, such as DMD and CPD, were increased by urea supplementation $(\mathrm{p}<0.01)$, and NFCD was higher with increasing levels of urea supplementation $(\mathrm{p}=0.028)$. Supplementation of urea did not change the OMD, NDFD, or ADFD. There was an increase in $\mathrm{N}$ intake $(\mathrm{p}<0.001)$ and retained $\mathrm{N}$ $(p=0.042)$ with increasing urea levels.

\section{Effect of urea supplementation on sheep performance}

Supplementation of urea increased ADG $(p=0.024)$, but decreased HCW percentage $(p=0.017$; Table-4). Conversely, FE, CCW, and dressing percentage were not influenced by urea supplementation.

\section{Discussion}

The aim of the present study was to investigate the effect of urea supplementation on rumen fermentation, intake, nutrient digestibility, and production performance in sheep. According to Khattab et al. [6], rumen fermentation products are represented in terms of $\mathrm{pH}, \mathrm{NH}_{3}-\mathrm{N}$ concentration, and total VFA composition; this is especially true for $\mathrm{NH}_{3}-\mathrm{N}$, which is an important nitrogen source for microbial protein synthesis and growth in the rumen [5]. Productive performance (ADG, $\mathrm{HCW}$, and $\mathrm{CCW}$ ) is an important indicator of sheep production [4]. Nutrient utilization can also be represented in the form of intake and nutrient digestibility parameters [2].

Table-2: Influence of urea supplementation ( $\mathrm{g} / \mathrm{kg}$ dry matter intake) on rumen fermentation of sheep.

\begin{tabular}{|c|c|c|c|c|c|c|c|c|}
\hline Response parameter & Unit & $\mathbf{n}$ & Intercept & SE intercept & Slope & SE slope & p-value & RMSE \\
\hline $\mathrm{pH}$ & - & 40 & 6.49 & 0.086 & 0.007 & 0.002 & 0.008 & 1.191 \\
\hline Total VFA & $\mathrm{mmol} / \mathrm{L}$ & 26 & 9.46 & 0.453 & 0.019 & 0.016 & 0.242 & 1.117 \\
\hline $\mathrm{C}_{2}$ & $\mathrm{~mol} / 100 \mathrm{~mol}$ & 24 & 7.59 & 0.297 & -0.006 & 0.008 & 0.469 & 1.232 \\
\hline $\mathrm{C}_{3}^{2}$ & $\mathrm{~mol} / 100 \mathrm{~mol}$ & 24 & 4.76 & 0.212 & -0.011 & 0.009 & 0.269 & 1.331 \\
\hline $\mathrm{C}_{4}^{3}$ & $\mathrm{~mol} / 100 \mathrm{~mol}$ & 24 & 3.21 & 0.252 & 0.010 & 0.004 & 0.033 & 1.002 \\
\hline isoC $_{4}$ & $\mathrm{~mol} / 100 \mathrm{~mol}$ & 15 & 1.12 & 0.106 & -0.011 & 0.003 & 0.006 & 0.821 \\
\hline $\mathrm{C}_{5}$ & $\mathrm{~mol} / 100 \mathrm{~mol}$ & 19 & 1.34 & 0.104 & 0.002 & 0.002 & 0.327 & 1.023 \\
\hline isoC $_{5}$ & $\mathrm{~mol} / 100 \mathrm{~mol}$ & 15 & 1.23 & 0.141 & 0.002 & 0.002 & 0.348 & 0.911 \\
\hline $\mathrm{C}_{2} / \mathrm{C}_{3}$ & - & 24 & 1.79 & 0.080 & 0.003 & 0.003 & 0.309 & 1.038 \\
\hline $\mathrm{NH}_{3}-\mathrm{N}$ & $\mathrm{mmol} / \mathrm{L}$ & 34 & 2.88 & 0.355 & 0.071 & 0.012 & 0.012 & 1.584 \\
\hline $\mathrm{CH}_{4}$ & $\mathrm{~g} / \mathrm{kg} \mathrm{BW} 0.75$ & 6 & 1.36 & 0.028 & 0.015 & 0.001 & $<0.001$ & 0.550 \\
\hline Total protozoa & $\mathrm{log} / \mathrm{mL}$ & 6 & 3.17 & 0.464 & -0.018 & 0.020 & 0.429 & 0.776 \\
\hline Microbial N supply & $g / d$ & 6 & 1.99 & 0.383 & 0.021 & 0.036 & 0.619 & 1.191 \\
\hline
\end{tabular}

VFA=Volatile fatty acid, $\mathrm{C}_{2}=$ Acetate, $\mathrm{C}_{3}=$ Propionate, $\mathrm{C}_{4}=$ Butyrate, $\mathrm{C}_{5}=$ Valerate, $\mathrm{NH}_{3}=\mathrm{Ammonia}_{2} \mathrm{CH}_{4}=$ Methane, $\mathrm{SE}=$ Standard error, $\mathrm{RMSE}=$ Root mean square error

Table-3: Influence of urea supplementation ( $\mathrm{g} / \mathrm{kg}$ DMI) on nutrient intake and digestibility of sheep.

\begin{tabular}{|c|c|c|c|c|c|c|c|c|}
\hline Response parameter & Unit & $\mathbf{n}$ & Intercept & SE intercept & Slope & SE slope & p-value & RMSE \\
\hline DMI & $\mathrm{g} / \mathrm{kg} \mathrm{BW} \mathrm{W}^{0.75}$ & 58 & 7.98 & 0.295 & 0.023 & 0.008 & 0.004 & 1.178 \\
\hline OMI & $\mathrm{g} / \mathrm{kg} \mathrm{BW} 0.75$ & 25 & 8.11 & 0.359 & 0.007 & 0.008 & 0.419 & 0.918 \\
\hline CPI & $\mathrm{g} / \mathrm{kg} \mathrm{BW} 0.75$ & 19 & 2.77 & 0.431 & 0.034 & 0.008 & 0.001 & 0.799 \\
\hline MEI & $\mathrm{g} / \mathrm{kg} \mathrm{BW} 0.75$ & 6 & 15.82 & 2.242 & 0.495 & 0.056 & 0.013 & 0.569 \\
\hline NFCI & $\mathrm{g} / \mathrm{kg} \mathrm{BW} 0.75$ & 7 & 4.15 & 0.630 & 0.004 & 0.006 & 0.581 & 0.677 \\
\hline NDFI & $\mathrm{g} / \mathrm{kg} \mathrm{BW} 0.75$ & 25 & 5.95 & 0.204 & -0.003 & 0.008 & 0.744 & 1.208 \\
\hline ADFI & $\mathrm{g} / \mathrm{kg} \mathrm{BW} 0.75$ & 17 & 4.41 & 0.079 & 0.001 & 0.004 & 0.919 & 0.996 \\
\hline DMD & $\mathrm{g} / \mathrm{kg}$ & 47 & 23.34 & 0.470 & 0.024 & 0.014 & 0.096 & 1.297 \\
\hline OMD & $\mathrm{g} / \mathrm{kg}$ & 36 & 24.09 & 0.487 & 0.026 & 0.017 & 0.130 & 1.241 \\
\hline CPD & $\mathrm{g} / \mathrm{kg}$ & 19 & 25.54 & 0.807 & 0.086 & 0.027 & 0.009 & 1.160 \\
\hline NFCD & $\mathrm{g} / \mathrm{kg}$ & 3 & 27.82 & 0.068 & 0.080 & 0.004 & 0.028 & 0.496 \\
\hline NDFD & $\mathrm{g} / \mathrm{kg}$ & 30 & 21.88 & 0.785 & -0.005 & 0.024 & 0.854 & 1.117 \\
\hline ADFD & $\mathrm{g} / \mathrm{kg}$ & 21 & 18.91 & 1.238 & 0.009 & 0.033 & 0.799 & 0.496 \\
\hline $\mathrm{N}$ intake & $\mathrm{g} / \mathrm{kg} \mathrm{BW}^{0.75}$ & 29 & 1.28 & 0.061 & 0.016 & 0.004 & $<0.001$ & 1.117 \\
\hline Retained N & $\mathrm{g} / \mathrm{kg} \mathrm{N}$ intake & 20 & 14.32 & 1.317 & 0.256 & 0.109 & 0.042 & 1.152 \\
\hline
\end{tabular}

DMI=Dry matter intake, OMI=Organic matter intake, $\mathrm{CPI}=$ Crude protein intake, $\mathrm{MEI}=$ Metabolizable energy intake, $\mathrm{NFCI}=$ Non-fiber carbohydrate intake, NDFI=Neutral detergent fiber intake, ADFI=Acid detergent fiber intake; DMD=Dry matter digestibility, $\mathrm{OMD}=$ Organic matter digestibility, $\mathrm{CPD}=$ Crude protein digestibility, NFCD=Non-fiber carbohydrate digestibility, NDFD=Neutral detergent fiber digestibility, ADFD=Acid detergent fiber digestibility, SE=Standard error, RMSE: Root mean square error 
Table-4: Influence of urea supplementation ( $\mathrm{g} / \mathrm{kg}$ DMI) on sheep performance.

\begin{tabular}{llccccccc}
\hline Response parameter & Unit & n & Intercept & SE intercept & Slope & SE slope & p-value & RMSE \\
\hline ADG & g/kg BW 0.75 & 47 & 3.39 & 0.254 & 0.023 & 0.009 & 0.024 & 1.108 \\
FE & & 35 & 4.16 & 0.102 & 0.003 & 0.003 & 0.382 & 1.226 \\
HCW & $\%$ & 8 & 5.68 & 1.063 & -0.006 & 0.002 & 0.017 & 0.768 \\
CCW & $\%$ & 27 & 5.04 & 0.152 & -0.001 & 0.002 & 0.611 & 1.080 \\
Dressing & $\%$ & 23 & 7.07 & 0.023 & -0.002 & 0.002 & 0.336 & 1.207 \\
\hline
\end{tabular}

$\mathrm{ADG}=$ Average daily gain, $\mathrm{FE}=$ Feed efficiency, $\mathrm{HCW}=$ Hot carcass weight, $\mathrm{CCW}=$ Cold carcass weight, $\mathrm{SE}=\mathrm{Standard}$ error, RMSE= Root mean square error

\section{Effect of urea supplementation on rumen fermenta- tion in sheep}

Ruminal $\mathrm{pH}$ is the first indicator representing the fermentation characteristics in the rumen. Fermentation and chemical rate differences between supplemental feed sources are reflected by $\mathrm{pH}$ curves [12]. The present meta-analysis study revealed an increase in the rumen $\mathrm{pH}$ of sheep following urea supplementation. Supplementation of urea at 3.5$31 \mathrm{~g} / \mathrm{kg}$ increased the $\mathrm{pH}$ value from 0.04 to 0.36 of the initial value. The $\mathrm{pH}$ values remained within a normal range of 5.5-7.0 [31,32]. Aschenbach et al. [32] reported that NPN fermentation in the rumen may release excess $\mathrm{NH}_{3}-\mathrm{N}$ and thus increase $\mathrm{pH}$. Furthermore, rumen bacteria convert urea into increased ruminal $\mathrm{NH}_{3}-\mathrm{N}$, which is a potent buffer. Ammonia accumulation from urea degradation may increase ruminal $\mathrm{pH}$ [13]. The rate of ureagenesis determines the disposal of bicarbonate and affects the maintenance of $\mathrm{pH}$ homeostasis [14].

In the present meta-analysis study, increasing $\mathrm{pH}$ values were concomitant with increases in $\mathrm{NH}_{3}-\mathrm{N}$ concentration after urea supplementation. It is widely known that urea provides a source of $\mathrm{N}$ for microbial protein synthesis. Other studies have reported that the rumen concentration of $\mathrm{NH}_{3}-\mathrm{N}$ increases linearly with increasing NPN supplementation levels $[5,15]$. The level of $\mathrm{NH}_{3}-\mathrm{N}$ in the ruminal fluid is important since it greatly affects rumen microbial growth [6]. As a rumen-degradable protein source, urea can increase microbial CP synthesis production and thus increase the metabolizable protein supply to host animals [13].

Moreover, more than $50 \%$ of dietary $\mathrm{N}$ is passed directly through the $\mathrm{NH}_{3}-\mathrm{N}$ pool in sheep [33]. Theoretically, urea supplementation increases the availability of $\mathrm{N}$ sources from diets with varying protein contents. Nonetheless, it is interesting to note that an increase in $\mathrm{NH}_{3}-\mathrm{N}$ levels due to urea supplementation occurred in both low-quality $[3,16,17]$ and high-quality diets $[5,6,15,18,19]$; this may be connected to the theory that the length of time during which ruminal microbes have access to $\mathrm{N}$ source substrate is reduced [2], thereby potentially increasing protein synthesis by bacteria [6] and protozoa [13]. Ruminants that consume low-quality forage efficiently use urea as a source of $\mathrm{N}$ supplementation [3]; however, urea supplementation should be balanced with the intake of soluble carbohydrates. Kozloski et al. [23] reported that sheep supplemented with urea alone had an increased $\mathrm{N}$ intake; however, most of this additional $\mathrm{N}$ was excreted in the urine. The minimum $\mathrm{NH}_{3}-\mathrm{N}$ requirement for microbial growth and activity depends on carbohydrate availability. As such, dietary manipulation should be conducted to obtain the optimal ruminal energy supply and provide the appropriate amount of available $\mathrm{N}$ [34].

Ruminal $\mathrm{NH}_{3}-\mathrm{N}$ is an equilibrium between dietary $\mathrm{N}$ degradation, microbial protein synthesis utilization, and $\mathrm{N}$ absorption. Greater $\mathrm{NH}_{3}-\mathrm{N}$ production from dietary sources is not necessarily reflected in a higher ruminal $\mathrm{NH}_{3}-\mathrm{N}$ concentration [14]. The current meta-analysis shows urea supplementation had a minor effect on the microbial $\mathrm{N}$ supply and total protozoa population. In agreement with the present findings, Zhao et al. [3] reported that urea supplementation does not affect microbial $\mathrm{N}$ or escaped $\mathrm{N}$ from feed. This effect is probably due to the regulation of bacterial equilibrium in the rumen ecosystem. The high-fiber content in some basal diets does not cause dramatic changes in microbial growth because it is slowly ingested [12]. For example, under dry pasture conditions, energy source supplements are more necessary than nitrogen supplements to accelerate microbial protein synthesis in the rumen for urea [35]. The lack of change in total protozoa is likely due to the interrelationships between protozoa and ruminal bacteria in the N-cycle. Protozoa engulf large numbers of ruminal bacteria and compete with ruminal bacteria for nutrients [36]. The total protozoa population was not affected by dietary urea supplementation [20]. Although not significant, the microbial $\mathrm{N}$ supply still showed a positive trend. A lack of significant differences in the microbial $\mathrm{N}$ supply and total protozoa population indicates that, in urea-supplemented diets, the adaptation factor related to microbial ecosystem changes must be monitored. Since there was no change in the protozoa population nor the microbial $\mathrm{N}$ supply, the molar proportion of total VFAs did not change. In agreement with the present study, Xu et al. [5] noted that similar concentrations of acetate, propionate, or total VFAs could be due to a similar proportion of carbohydrates in the diets. The relative concentration of total VFAs is often assumed to represent the carbohydrate fermentation rate and microbial conditions in the rumen [31]. Despite the effect on total VFAs, acetate and propionate were not affected by urea supplementation, and the butyrate 
proportion experienced a relatively positive effect. As such, an increase in butyrate formation through urea supplementation may explain the role of butyrates in enhancing $\mathrm{N}$ degradation in the rumen [36]. Butyrate/butyric acid increases the total urea synthesis and is degraded in the rumen and stimulates the transfer of urea to the gastrointestinal tract [37]. The present meta-analysis study reveals a positive association between urea degradation and the butyrate proportion.

The increased tendency for higher $\mathrm{CH}_{4}$ production at higher levels of urea supplementation appears to be related to the increased utilized $\mathrm{N}$ availability, which is used by methanogenic archaea. A previous study revealed that $\mathrm{CH}_{4}$ production was positively correlated with the microbial population and $\mathrm{NH}_{3}-\mathrm{N}$ concentration [38]. Conversely, Bharanidharan et al. [39] revealed that rumen metabolites and $\mathrm{NH}_{3}-\mathrm{N}$ concentration correlate negatively $(p<0.001)$ with methane production. Furthermore, different methods of feeding (total mixed rations [TMRs] or concentrate and roughage fed separately) lead to different implications with regard to the relationship between $\mathrm{N}$ utilization and $\mathrm{CH}_{4}$ production. Another explanation for this higher $\mathrm{CH}_{4}$ production in the presence of urea supplementation may be due to the interrelationship between butyrate and the $\mathrm{CH}_{4}$ pathway. A simultaneous increase in butyrate (producing $\mathrm{H}_{2}$ ) and decrease in isobutyrate affects the regulation of $\mathrm{H}_{2}$ in the production of $\mathrm{CH}_{4}$. In agreement with the present findings, a study by Granja-Salcedo et al. [40] reported that long-term encapsulated urea supplementation increases the butyrate proportion and positively correlates with Archaea Euryarchaeota (Methanobacterium, Methanobrevibacter, and Methanomassiliicoccus). In addition, Dong et al. [41] also observed that Methanobrevibacter has a positive $(\mathrm{p}<0.05)$ relationship with butyrate production.

Furthermore, this explanation reflects the correlation between methanogenesis function and ruminal fermentation variables. Enteric $\mathrm{CH}_{4}$ emission represents a loss of energy from ruminants, which could be potentially (at least partially) utilized for production and reproduction [42]. Partitioning of the fermented OM between ruminal microbes, total VFA, and $\mathrm{CH}_{4}$ depends on: (1) The availability of substrates and pathways of cellular material synthesis; (2) the adenosine triphosphate requirements of the microbes; and (3) the turnover of microbial cells within rumen ecosystems [43].

\section{Effect of urea supplementation on nutrient intake and digestibility in sheep}

DMI, CPI, and MEI increased with dietary urea supplementation. These results may be attributed to the increase of ruminally available $\mathrm{N}$ after the $\mathrm{NH}_{3}-\mathrm{N}$ concentration increased. The optimal level of available $\mathrm{N}$ can increase microbial growth and apparently increase dietary intake. The addition of urea can increase DMI and CPI due to an improvement in microbial fermentation when the $\mathrm{NH}_{3}-\mathrm{N}$ concentration increases in the rumen $[5,44]$, thus improving availability in the intestines [45]. As discussed above, urea supplementation can increase the $\mathrm{pH}$ in the rumen and have a positive effect on the absorption of rumen $\mathrm{NH}_{3}-\mathrm{N}$ into the blood [5]. Variable results have been reported by other authors; For instance, Wang et al. [1] reported that DMI is reduced in Dorper crossbreed sheep after urea supplementation treatment of up to $25 \mathrm{~g} / \mathrm{kg}$ DM. In addition, Zhao et al. [3] suggested that the response to urea supplementation may be lower if the diet contains high CP levels and results in higher NDF intake.

Conversely, Manyuchi et al. [21], McGuire et al. [2], and Xu et al. [5] stated that DMI and CPI are higher in sheep who receive urea supplementation than in non-supplemented animals. Different results were shown by Kozloski et al. [12] and Currier et al. [46], who reported that supplemental urea to ruminants consuming low-quality roughage does not affect an animal's DMI. Although there was no change in DMI, we assume a change in the intake of other nutrient components. There are several explanations for these differing nutrient intake results related to urea supplementation in sheep, including: (1) Differences in $\mathrm{CP}$ concentration and the quality of the original basal diets [1]; (2) differences in the chemical and/ or physical characteristics of the forage/feedstuff $[15,47]$; and (3) differences in the slow-fast degradable carbohydrate and/or forage-concentrate composition of the basal diets $[3,44]$.

Accordingly, increased feed intake in response to urea supplementation may be attributed to the mechanism of $\mathrm{N}$ and $\mathrm{C}$ synchronization utilization in the rumen, which can increase the rate of microbial growth [5]. Urea supplementation may not clearly influence protein synthesis in animal feed isoenergetic concentrate diets, even though the fermentation characteristics of the rumen are changed [15]. Notably, urea supplementation can increase resilience to parasitism, thereby improving feed intake and enhancing resistance mechanisms against Haemonchus contortus and Trichostrongylus colubriformis worms in sheep on low-quality diets [45]. Furthermore, it is reasonable to conclude that high DMI resulted from enhanced host immunological responses arising from an improved nutritional status after urea supplementation. Urea has also been reported to improve $\mathrm{N}$ intake in diets rich in tannin-containing tree leaves, by providing extra $\mathrm{N}$ sources for ruminal microbes [22]. Moreover, tannin activity can be neutralized [48] and reduced [49] by urea supplementation.

Based on this meta-analysis, it is apparent that urea supplementation influences DMD, CPD, and NFCD. The increase in DMI and CPI induces positive feedback on nutrient digestibility in the digestive tract of sheep. Urea supplementation benefits the function of ruminal microbes and thus improves 
ruminant production [19]. Moreover, urea supplementation has been shown to improve total tract digestibility in sheep consuming low-quality forage [2]. Another explanation is that urea can increase resilience to parasitism because of improved nutritional status. Adding 3\% urea to basal diets can increase feed digestibility by $10-15 \%$ [45]. Although urea improves digestibility in various types of diets, McGuire et al. [2] and Dixon et al. [17] reported that urea supplementation is more optimally applied to diets based on low-quality forage; increasing the availability of NPN sources would help to address the lack of CP content derived from low-quality forage. Small quantities of essential nutrients, including urea, can perform acceptably with low digestibility forage $[17,43,46]$. Apparently, from the perspective of digestibility, low urea levels $(<3 \mathrm{~g} / \mathrm{kg} \mathrm{DM})$ are optimally used in diets based on low-quality forage. In contrast, high urea levels (up to $30 \mathrm{~g} / \mathrm{kg} \mathrm{DM}$ ) are effectively applied to high concentrate/TMR-based diets. There is a need for further evaluations of this hypothesis. Urea is also likely useful when given with low-protein supplements that do not satisfy $\mathrm{N}$ microbial requirements from degraded fractions [50]. In a previous study, feed intake did not always positively affect digestibility: Fecal DM excretion increased as nutrient intake increased, indicating a greater passage of digesta after $\mathrm{N}$ supplementation [47]. Zhao et al. [3] found that direct urea spray added to maize stover (up to $39.5 \%$ of a dietary level) reduced the digestibility of nutrients. High urea levels supplemented in diets may cause $\mathrm{N}$ loss during micturition and decrease $\mathrm{N}$ utilization efficiency [1]. However, this explanation differs from the current results of our meta-analysis; this difference could be due to variations in basal diet characteristics.

In addition, CPD is positively correlated with dietary $\mathrm{CP}$ level when metabolic fecal $\mathrm{N}$ is constant [5]. Apparent total tract $\mathrm{N}$ digestibility for urea-supplemented treatments is approximately $110 \%$ higher than for unsupplemented treatments [46]. Accordingly, CPD increases following the increase in $\mathrm{N}$ availability resulting from urea supplementation. As such, CPD may have a positive relationship with $\mathrm{N}$ intake and retained $\mathrm{N}$. The greater digestibility of $\mathrm{N}$ supplements indicates that the proportion of $\mathrm{N}$ intake increased in line with the decrease in metabolic fecal $N$ [2]. Nonetheless, the mechanism by which $N$ retention is higher under urea supplementation than unsupplemented treatment is unclear.

Moreover, urea supplementation may increase feed degradability, thus increasing sugar availability for improved nutritional status [23]. Furthermore, greater $\mathrm{N}$ retention is caused by higher MEI and higher microbial protein entering the small intestine in sheep. The characteristic rapid degradation of urea will increase $\mathrm{N}$ utilization from the fermentation process in the rumen. Increases in total ruminal degradable $\mathrm{N}$ were most likely due to the decomposition of supplemented urea in the rumen [3]. We must, therefore, consider that $\mathrm{N}$ retention and digestibility were positively affected by the characteristics of the base feed [47] and the proportion of $\mathrm{N}$ to non-structural carbohydrates in the diets [11].

Effect of urea supplementation on sheep performance

Urea supplementation had a positive effect on ADG. Supplemental urea also numerically $(\mathrm{p}=0.382)$ increased FE for a better feed cost to gain ratio. Based on the present study, it is clear that urea can increase DMI, CPI, DMD, and CPD. The increases in intake and digestibility are generally known to positively affect body weight gain, except for carcass quality. This increase in fattening performance is related to the increase in CPD, due to rumen microbes having a quickly available $\mathrm{N}$ source from urea [24]. Accordingly, improving microbial growth in the rumen may increase daily body weight gain. In addition, animal growth performance is likely enhanced by supplementing diets with urea at levels beyond that necessary for maximal rumen microbial growth [51]. As explained above, urea supplementation also gives rise to immunological responses in sheep [45]. When sheep are raised under good health conditions, their ADG primarily depends on their DMI and nutrient digestibility [5]. Urea supplementation also promotes increased feed intake to help sheep maintain their body condition, thus improving their final body weight gain [25]. In contrast, Wang et al. [1] stated that urea supplementation at $25 \mathrm{~g} / \mathrm{kg} \mathrm{DM}$ may reduce the growth performance of Dorper sheep fed a diet with a 50:50 concentrate to forage ratio. We must consider that the urea degradation rate could be more rapid than the $\mathrm{NH}_{3}-\mathrm{N}$ utilization rate by rumen microbes, leading to ruminal accumulation and absorption. Therefore, it is necessary to determine the optimal level of urea supplementation for the specific diet (characteristics and/ or ratio) fed to the sheep breed of interest [5]. With a different form of urea (SRU), NPN supplementation exhibits consistent improvement in the LWG and FE of beef cattle [10].

Urea supplementation had a minor effect on $\mathrm{CCW}$ and dressing percentage; however, the $\mathrm{HCW}$ parameter tended to decrease. This decrease in carcass value appears to be associated with increased non-carcass values caused by urea supplementation. The fat percentage of the kidneys, pelvic area, and heart increase linearly with increasing urea supplementation [52]. Unfortunately, non-carcass proportion was not widely reported in the literature used for this meta-analysis and thus could not be integrated into the dataset and analysis; thus, this explanation remains unclear. In agreement with the present meta-analysis findings, a study by Cosby and Stanton [53] reported that although the feed cost of gain is lowest for a urea-supplemented diet, natural protein supplemented in basal diets is still competitive and creates greater carcass weight compared to urea supplementation. 
To the best of our knowledge, the present study is the first to apply a meta-analysis to objectively review the effect of urea supplementation on the performance of sheep. There is an important role for well-designed research experiments to provide efficacy results that can support farmers and industry users in making the most profitable and efficient sheep farm management decisions.

\section{Conclusion}

This meta-analysis revealed that urea, as a lowcost $\mathrm{N}$ supplement, is a reasonable choice for improving rumen fermentation, nutrient intake, digestibility, and sheep performance. Urea supplementation consistently improves $\mathrm{NH}_{3}-\mathrm{N}$ production, $\mathrm{CPI}, \mathrm{CPD}, \mathrm{N}$ intake, and ADG in sheep; however, urea supplementation also tends to increase enteric $\mathrm{CH}_{4}$ emissions and decreases carcass performance. This study is limited to the findings available in the Scopus database so, further studies should be conducted to involve the various findings from various databases.

\section{Authors' Contributions}

TW: Investigation and writing of the manuscript. MMS: Methodology and software experiments, formal analysis, and visualization. YK and TO: Conceptualization and validation. SS: Revised the manuscript. AJ: Conceptualization, data curation, writing of the manuscript, supervision, and validation. All authors read and approved the final manuscript.

\section{Acknowledgments}

The authors are thankful to the Animal Feed and Nutrition Modelling Research Group, Faculty of Animal Science, IPB University, Indonesia, for providing a collaborative platform among the research fellows across various institutions. The authors did not receive any funds for this study.

\section{Competing Interests} interests.

The authors declare that they have no competing

\section{Publisher's Note}

Veterinary World remains neutral with regard to jurisdictional claims in published institutional affiliation.

\section{References}

1. Wang, B., Ma, T., Deng, K.D., Jiang, C.G. and Diao, Q.Y. (2015) Effect of urea supplementation on performance and safety in diets of Dorper crossbred sheep. J. Anim. Physiol. Anim. Nutr., 100(5): 902-910.

2. Mcguire, D.L., Bohnert, D.W., Schauer, C.S., Falck, S.J. and Cooke, R.F. (2013) Daily and alternate day supplementation of urea or soybean meal to ruminants consuming low-quality cool-season forage: Effects on efficiency of nitrogen use and nutrient digestion. Livest. Sci., 155(2): 205-213.

3. Zhao, X.G., An, J., Luo, Q.J. and Tan, Z.L. (2007) Effect of method and level of urea supplementation on nutrient utilization and ruminal fermentation in sheep fed a maize stover-based diet. J. Appl. Anim. Res., 31(2): 125-130.

4. Voltolini, T.V., de Moraes, S.A., de Araújo, G.G.L., de Oliveira, P.L.T. and Pereira, L.G.R. (2010) Urea levels in multiple supplements for lambs grazing on buffelgrass. Maringá, 32(4): 461-465.

5. Xu, Y., Li, Z., Moraes, L.E., Shen, J., Yu, Z. and Zhu, W. (2019) Effects of incremental urea supplementation on rumen fermentation, nutrient digestion, plasma metabolites, and growth performance in fattening lambs. Animals, 9(9): 682

6. Khattab, I.M., Salem, A.Z.M., Abdel-wahed, A.M. and Kewan, K.Z. (2013) Effects of urea supplementation on nutrient digestibility, nitrogen utilisation and rumen fermentation in sheep fed diets containing dates. Livest. Sci., 155(2-3): 223-229.

7. Sauvant, D., Letourneau-Montminy, M.P., Schmidely, P., Boval, M., Loncke, C. and Daniel, J.B. (2020) Review: Use and misuse of meta-analysis in animal science. Animal, 14(2): s207-s222.

8. Salami, S.A., Moran, C.A., Warren, H.E. and Taylorpickard, J. (2020) A meta-analysis of the effects of slow-release urea supplementation on the performance of beef cattle. Animals, 10(4): 657.

9. Stewart, G.S. and Smith, C.P. (2005) Urea nitrogen salvage mechanisms and their relevance to ruminants, non-ruminants and man. Nutr. Res. Rev., 18(1): 49-62.

10. Schuba, J., Südekum, K.H., Pfeffer, E. and Jayanegara, A. (2017) Excretion of faecal, urinary urea and urinary nonurea nitrogen by four ruminant species as influenced by dietary nitrogen intake: A meta-analysis. Livest. Sci., 198(April 2017): 82-88.

11. Sevim, Ö. and Önol, A.G. (2019) Supplemental slow-release urea and non-structural carbohydrates: Effect on digestibility and some rumen parameters of sheep and goats. J. Anim. Plant Sci., 29(1): 1-7.

12. Kozloski, G.V., Reffatti, M.V., Sanchez, L.M.B., Lima, L.D., Cadorin, R.L. Jr., Härter, C.J. and Fiorentini, G. (2007) Intake and digestion by lambs fed low-quality grass hay supplemented or not with urea, casein or cassava meal. Anim. Feed Sci. Technol., 136(3): 191-202.

13. Zhang, S., Cheng, L., Guo, X., Ma, C., Guo, A. and Moonsan, Y. (2014) Effects of urea supplementation on rumen fermentation characteristics and protozoa population in vitro. J. Appl. Anim. Res., 44(1): 1-4.

14. Saro, C., Mateo, J., Andrês, S., Mateos, I., Ranilla, M.J., López, M. and Giráldez, A. (2019) Replacing soybean meal with urea in diets for heavy fattening lambs: Effects on growth, metabolic profile and meat quality. Animals, 9(11): 974.

15. Sano, H. and Shibasaki, S. (2011) Effects of urea and soybean meal supplementation on rates of plasma leucine turnover and protein synthesis in sheep fed concentrate-based diets. J. Appl. Anim. Res., 39(3): 239-244.

16. Krebs, G.L., Howard, D.M. and Dods, K. (2007) Feeding Acacia saligna to sheep and goats with or without the addition of urea or polyethylene glycol. Asian Australas. $J$. Anim. Sci., 20(10): 1551-1556.

17. Dixon, R.M., Karda, W., Hosking, B.J. and Egan, A.R. (2003) Effects of oilseed meals and grain urea supplements fed infrequently on digestion in sheep 2. Cereal straw diets. Anim. Feed Sci. Technol., 110(1-4): 95-110.

18. Adejoro, F.A., Hassen, A., Akanmu, A.M. and Morgavi, D.P. (2020) Replacing urea with nitrate as a non-protein nitrogen source increases growth and reduces methane production, while acacia tannin has no effect in lambs. Anim. Feed Sci. Technol., 259: 114360.

19. Sano, H., Shibasaki, S. and Sawada, H. (2009) The effect of the source of nitrogen supplementation on nitrogen balance, rates of plasma leucine turnover, protein synthesis and degradation in sheep. Arch. Anim. Nutr., 63(5): 401-412. 
20. Li, L., Davis, J., Nolan, J. and Hegarty, R. (2012) An initial investigation on rumen fermentation pattern and methane emission of sheep offered diets containing urea or nitrate as the nitrogen source. Anim. Prod. Sci., 52(7): 653-658.

21. Manyuchi, B., Hovell, F.D.D., Ndlovu, L.R., Topps, J.H. and Tigere, A. (1996) Feeding Napier hay as a supplement to sheep given poor quality natural pasture hay: Effects of the level of Napier hay supplement and inclusion of urea in the basal diet on intake and digestibility. Anim. Feed Sci. Technol., 63(1-4): 123-135.

22. Habib, G., Raza, M. and Saleem, M. (2008) Effect of tree leaves with or without urea as a feed supplement on nutrient digestion and nitrogen balance in sheep. Anim. Feed Sci. Technol., 144(3-4): 335-343.

23. Kozloski, G.V., Sanchez, L.M.B., Cadorin, R.L. Jr., Reffatti, M.V., Neto, D.P. and Lima, L.D. (2006) Intake and digestion by lambs of dwarf elephant grass (Pennisetum purpureum Schum. cv. Mott) hay or hay supplemented with urea and different levels of cracked corn grain. Anim. Feed Sci. Technol., 125(1): 111-122.

24. Canbolat, Ö. and Karabulut, A. (2010) Effect of urea and oregano oil supplementation on growth performance and carcass characteristics of lamb fed diets containing different amounts of energy and protein. Turk. J. Vet. Anim. Sci., 34(2): 119-128.

25. Sweeny, J.P.A., Surridge, V., Humphry, P.S., Pugh, H. and Mamo, K. (2014) Benefits of different urea supplementation methods on the production performances of Merino sheep. Vet. J., 200(3): 398-403.

26. Thanh, V.D., Thu, N.V. and Preston, T.R. (2012) Effect of potassium nitrate or urea as NPN sources associated with mangosteen peel (Garcinia mangostana) on methane production, rumen parameters and growth performance of Phan Rang sheep in the Mekong delta of Vietnam. Livest. Res. Rural. Dev., 24(4). Available from: http:// www.lrrd.org/lrrd24/4/thanh24073.htm. Retrieved on 01-03-2021.

27. Page, M.J., McKenzie, J.E., Bossuyt, P.M., Boutron, I., Hoffmann, T.C., Mulrow, C.D., Shamseer L, Tetzlaff, J.M., Akl, E.A., Brennan, S.E., Chou, R., Glanville, J., Grimshaw, J.M., Hróbjartsson, A., Lalu, M.M., Li, T., Loder, E.W., Mayo-Wilson, E., McDonald, S., McGuinness, L.A., Stewart, L.A., Thomas, J., Tricco, A.C., Welch, V.A., Whiting, P. and Moher, D. (2021) The PRISMA 2020 statement: An updated guideline for reporting systematic reviews. BMJ, 372

28. Sauvant, D., Schmidely, P., Daudin, J.J. and St-Pierre, N.R. (2008) Meta-analyses of experimental data in animal nutrition. Animal, 2(8): 1203-1214.

29. St-Pierre, N.R. (2001) Invited review: Integrating quantitative findings from multiple studies using a mixed model methodology. J. Dairy Sci., 84(4): 741-755.

30. Pinheiro, J., Bates, D., DebRoy, S., Sarkar, D., Authors, E., Heisterkamp, S., Van Willigen, B. and Ranke, J. (2021) Linear and Nonlinear Mixed Effects Models Description. Available from: https://cran.r-project.org/web/packages/ nlme/nlme.pdf. Retrieved on 19-04-2021.

31. Mcdonald, P., Edwards, R.A., Greenhalgh, J.F.D., Morgan, C.A., Sinclair, L.A. and Wilkinson, R.G. (2010) Animal Nutrition. $7^{\text {th }}$ ed. Pearson, London.

32. Aschenbach, J.R., Penner, G.B., Stumpff, F. and Gäbel, G. (2011) Ruminant nutrition symposium: Role of fermentation acid absorption in the regulation of ruminal $\mathrm{pH} . J$. Anim. Sci., 89(4): 1092-1107.

33. Abdoun, K., Stumpff, F. and Martens, H. (2006) Ammonia and urea transport across the rumen epithelium: A review. Anim. Health Res. Rev., 7(1/2): 43-59.

34. Henning, P.H., Steyn, D.G. and Meissner, H.H. (1993) Effect of synchronization of energy and nitrogen supply on ruminal characteristics and microbial growth. J. Anim. Sci.,
71(9): 2516-2528.

35. Farid, M.F.A., Abou-El Nasr, H.M., Hassan, N.I. and Swidan, F.Z. (1989) Long-term adaptation of sheep to low protein roughage diets: Effects of water deprivation and urea supplementation in the drinking water. J. Arid Environ., 16(2): 211-216.

36. Agarwal, U., Hu, Q., Baldwin, R.L. and Bequette, B.J. (2015) Role of rumen butyrate in the regulation of nitrogen utilization and urea nitrogen kinetics in growing sheep. $J$. Anim. Sci., 93(5): 2382-2390.

37. Whitelaw, F.G. and Milne, J.S. (1991) Urea degradation in sheep nourished by intragastric infusion: Effect of level and nature of energy inputs. Exp. Physiol., 76(1): 77-90.

38. Kara, K. (2018) Estimated ruminal digestion values and digestion end-products of concentrated mix feed after in vitro treatment with propionic acid. Vet. Med. Czech., 63(12): 537-545

39. Bharanidharan, R., Arokiyaraj, S., Kim, E.B., Lee, C.H., Woo, Y.W., Na, Y., Kim, D. and Kim, K.H. (2018) Ruminal methane emissions, metabolic, and microbial profile of Holstein steers fed forage and concentrate, separately or as a total mixed ration. PLoS One, 13(8): e0202446.

40. Granja-Salcedo, Y.T., Fernandes, R.M., de Araujo, R.C., Kishi, L.K., Berchielli, T.T., de Resende, F.D., Berndt, A. and Siqueira, G.R. (2019) Long-Term encapsulated nitrate supplementation modulates rumen microbial diversity and rumen fermentation to reduce methane emission in grazing steers. Front. Microbiol., 10: 614.

41. Dong, L., Ma, J., Tu, Y. and Diao, Q. (2019) Weaning methods affect ruminal methanogenic archaea composition and diversity in Holstein calves. J. Integr. Agric., 18(5): 1080-1092.

42. Jayanegara, J., Harahap, R.P., Ridla, M., Laconi, E.B. and Nahrowi. (2018) Chemical composition and methane emission of some tropical forage legumes from indonesia. AIP Conf. Proc., 2021(1): 050002.

43. Leng, R.A. and Nolan, J.V. (1984) Nitrogen metabolism in the rumen. J. Dairy Sci., 67(5): 1072-1089.

44. Galina, M.A., Guerrero, M. and Puga, C.D. (2007) Fattening Pelibuey lambs with sugar cane tops and corn complemented with or without slow intake urea supplement. Small Ruminant Res., 70(1): 101-109.

45. Knox, M.R. and Steel, J.W. (1999) The effects of urea supplementation on production and parasitological responses of sheep infected with Haemonchus contortus and Trichostrongylus colubriformis. Vet. Parasitol., 83(2): 123-135.

46. Currier, T.A., Bohnert, D.W., Falck, S.J., Schauer, C.S. and Bartle, S.J. (2004) Daily and alternate-day supplementation of urea or biuret to ruminants consuming low-quality forage: II. Effects on site of digestion and microbial efficiency in steers. J. Anim. Sci., 82(5): 1518-1527.

47. Doyle, P.T. and Panday, S.B. (1990) The feeding value of cereal straws for sheep. III. Supplementation with minerals or minerals and urea. Anim. Feed Sci. Technol., 29(1-2): 29-43.

48. Souri, M., Angaji, L. and Moeini, M.M. (2015) Deactivation of tannins in raisin stalk by polyethylene glycol-6000 effect on feed intake, digestibility, and nitrogen retention in sheep. Turk. J. Vet. Anim. Sci., 39(4): 443-449.

49. Frutos, P., Hervás, G., Giráldez, F.J. and Mantecón, A.R. (2004) Review. Tannins and ruminant nutrition. Span. J. Agric. Res., 2(2): 191-202.

50. Ørskov, E.R., Fraser, C., McDonald, I. and Smart, R.I. (1974) Digestion of concentrates in sheep 5. The effect of adding fish meal and urea together to cereal diets on protein digestion and utilization by young sheep. Br. J. Nutr., 31(1): 89-98.

51. Zinn, R.A., Borquez, J.L. and Plascencia, A. (1994) Influence of levels of supplemental urea on characteristics 
of digestion and growth performance of feedlot steers fed a fat-supplemented high-energy finishing diet. Prof. Anim. Sci., 10(1): 5-10.

52. Richeson, J.T., Rivera, J.D., Cranston, J.J., Abney, M.D. and Galyean, M.L. (2006) Effects of proportion of supplemental dietary crude protein supplied by urea on performance and carcass characteristics of beef cattle fed steam-flaked corn-based diets with wet corn gluten feed. Prof. Anim. Sci., 22(1): 33-40.

53. Cosby, N.T. and Stanton, T.L. (1997) Performance of feedlot steers supplemented with natural protein or urea during the early finishing phase. Prof. Anim. Sci., 13(3): 124-128.

$* * * * * * * *$ 